\title{
THE DIGITAL COMPETENCE IN THE INITIAL TRAINING. ESCAPE ROOMS: GAMIFIED ACTIVITIES FOR THE TRAINING OF EDUCATION PROFESSIONALS
}

\author{
Miriam Agreda Montoro, Ana Ma Ortiz Colón and Javier Rodríguez Moreno \\ Department of Pedagogy, Faculty of Humanities and Education Sciences of University of Jaén, Spain
}

\begin{abstract}
This work presents an educational innovation performed during the academic year 2018/2019, consisting in some escape room activities with the students of the Social Education and the Infant Education degrees from the University of Jaén. This kind of activity have maintained, for many years, certain popularity within the educational field, specially in compulsory stages of training; however, its usage in university classrooms has increased dramatically. Thus, they have been considered as an useful way to acquire competences in the university sphere, specially in Educational Science degrees. Aside from breaking the pattern of traditional methodologies, they also allow the implementation of new ways of teaching and learning using Information and Communication Technologies (ICT), and the development of metacognitive abilities. The general objective of this work is to present the didactic proposal developed, as well as the perception of the students after completing the activity.
\end{abstract}

\section{KEYWORDS}

Educational Technology, Higher Education, Teaching Qualification, Educational Innovation

\section{INTRODUCTION}

In the Spanish university the digital competence is one of the basic competences of citizens of the $21^{\text {st }}$ century, being considered as a transversal competence after the creation of the European Higher Education Area. On the other hand, the educational innovation in our higher teaching system needs to become a basic element of our daily tasks if we want to adapt the institutions to the employment and economic context of today's society, in line with the Digital Agenda for Europe of the European Commission (2014). If we make some history, from the appearance of the first web in the nineties, the world of technology has moved forward at a great speed, a breakneck speed that we are not fully aware of. For example, it was only ten years ago that WhatsApp started to incorporate within people's lives; in the decade of the 2000s the evolution of mobile technology was overwhelming, until reaching the predecessor devices of the ones that we have today; causing the migration of the $2 \mathrm{G}$ and $3 \mathrm{G}$ to $4 \mathrm{G}$ en 2011 ; eight years after, the $5 \mathrm{G}$ is starting to appear in our lives. Facts like this have led to the implementation of more and more devices equipped with a greater complexity and portability, becoming an extension of the body itself. This way, the number of applications and/or softwares has notoriously increased, providing a bigger stimulation, a greater visual capacity and dynamism, that seduces every user.

One of the fields where this reality can be clearly seen is leisure and free-time, where more and more platforms are being developed for video games and their developing, with a growing orientation towards films, through the creation of stories that seek the empathy among players and their connection with virtual reality.

This way, through the development of media, images, animations, videos, etc., virtual reality generates a double dimension, resulting in a wide development. 
First of all, it highlights the possibility to exploit VR with a greater presence. On the other hand, the fusion between the real world and virtual reality generates the augmented reality, with ubiquitous and timeless characteristics and a teaching-learning constructivist and connectivist approach, oriented to the acquisition of competences of the $21^{\text {st }}$ century (Wang, Callaghan, Bernhardt, White, \& Peña-Ríos, 2018). This way, innovation in the education reaches a wider development in that teaching-learning process.

All of these resources represent the support for the development of methodologies in the classroom that contribute to the interaction with students and among them. In this sense, escape rooms contribute to create training spaces that facilitate learning, being essential for the metacognitive development. Thus, educational escape rooms acquire functionality and significance for learning, as they work on the contents of the different subjects and courses through the game.

For all these reasons, it is worth to highlight the scientific production regarding the studies in this sphere, specially in the last two years, in disciplines related with health, exact sciences and social sciences.

\section{THEORETICAL FRAMEWORK}

\subsection{Escape Room: A Brief Concept}

The origin of escape rooms, although they existed already in the virtual world, comes from the REG (Real Escape Games), created by the scriptwriter and film director Takao Kato of the company SCRAP (2007) in Japan; a Japanese company that developed an adventure-based game to solve different tasks, mainly puzzles, where different groups of five or six people participated. Later, they were performed organizing big massive events in wider spaces. From 2012 and 2013 onwards, escape rooms developed globally, starting in Asia, then in Europe and arriving to countries like Australia, the United States and Canada (Nicholson, 2015, 2018).

Authors like Nicholson (2015) y Simkins (2015) state that escape rooms have had five precedents:

- The growing and evolution of role-playing games.

- $\quad$ Treasure hunts and riddles.

- The development of interactive haunted houses and theaters.

- The film industry and adventure games.

- $\quad$ The progress followed by the entertainment industry, more and more worried about the interests and requests of users, adapting their themes to them.

This way, an escape room is a game of real action ruled by the cooperative work of the team, whose purpose is to escape a room full of riddles, clues and puzzles that participants must solve properly. Every escape room game is set in a specific theme. Normally, the main objective is to escape the room in a specified time, which normally is 60 minutes (Nicholson, 2015)

\subsection{Escape Rooms in Education}

The human being learns in a more efficient way when presented with activities based on games and own experimentation. In this regard, as escape rooms are activities based in a game, we believe it is appropriate to highlight the term gamification, as an attractive learning technique for students that transfers the mechanics of the game to the educational field, in order to achieve better results, whether to interiorize knowledge, improve abilities or to reward certain actions. This way, the interest and curiosity of students is increased, whose main objective is to attain the didactic objectives in, a priori, non-educational environments (Deterding, Dixon, Khaled, \& Nacke, 2011; Deterding, Sicart, Nacke, O'Hara, \& Dixon, 2011; Rice, 2012). 
Csikszentmihalyi (2012) presents seven elements that may be integrated within the teaching-learning process of escape rooms that were developed in his flow theory, which are:

a) To define and specify a goal explicitly: when the teacher decides to carry out an escape room in the classroom, students know the final goal of the activity, to escape the room before the time is up.

b) Realism in the achievement of the goal: the final objective depends on the students, their energy and effort in the performance of the challenges to obtain it.

c) The challenge determines the activity: that is why the attention of the students must be constant and continuous to achieve the final challenge.

d) The development of the escape room should not lead to stress or anxiety: although the performance of the activity requires effort and concentration, it is also based on a gamified environment with a high level of motivation.

e) The game generates a continuous feedback: a coordinator will be in charge of narrating the story and provide support and help to students when in doubt, blocking, etc., indicating how to continue with the game.

f) To make the students feel in control of the game: as the tasks involve some lack of knowledge about what the students will find or will have to do.

g) There is an alteration in the time perception: being a gamified environment where it is necessary to maintain concentration, students lose track of time, causing them to feel that they have invested less time than they actually have.

For these reasons, gamification contributes to transform Higher Education in order to adapt it to the reality where we live, using the potential of games, their dynamics and mechanics to benefit and enrich the learning scenarios, as they become factors and motivating elements, both for teachers and students in the development and acquisition of the competences of the different degrees. It is necessary to take into account that the challenge and the possibility of wining points generates and causes a satisfaction feeling in students, because in order to get them, there must have been a series of achievements in a progressive way, and, therefore, they are aware of the progress they have followed to achieve the final goal (EducaLab, 2015; Ochoa, 2014).

\section{EDUCATIONAL INNOVATION PROPOSAL IN THE EARLY CHILDHOOD EDUCATION AND SOCIAL EDUCATION DEGREES OF THE UNIVERSITY OF JAÉN}

The experience developed has taken the form of the implementation of an innovative didactic proposal with students from the Social Education degree (1st and 2nd course) and Early Childhood Education degree (1st course). In Table 1 is shown the number of students participating and the subjects where the activity was carried out. It is worth mentioning that the performance of the escape rooms was developed in a different way in each degree. 
Table 1. Characteristics of participating students

\begin{tabular}{ccc}
\hline Degree-Course & No. of participating students & Subject \\
\hline $\begin{array}{c}\text { Early Childhood } \\
\text { Education degree }\left(\mathbf{1}^{\text {st }}\right. \\
\text { course) }\end{array}$ & 90 & $\begin{array}{c}\text { General Didactics in Early Childhood } \\
\text { Education }\end{array}$ \\
\hline $\begin{array}{c}\text { Social Education degree } \\
\left(\mathbf{1}^{\text {st }} \text { course }\right)\end{array}$ & 75 & Permanent Education \\
\hline $\begin{array}{c}\text { Social Education degree } \\
\left(\mathbf{2}^{\text {nd }} \text { course }\right)\end{array}$ & 72 & Organization and Management of \\
& & Educational Institutions for Social \\
\end{tabular}

\subsection{Description of the Didactic Proposal}

The decision of implementing escape rooms as a methodological alternative in the classroom originated from the teaching interest to know and analyze the acquisition of contents of the subject General Didactics in Early Childhood Education, an annual basic subject of great importance around which, the rest of the subjects of the degree are articulated. After the positive results of the experience, it was transfered to the Social Education degree, with important modifications: in this case the students design, develop and implement their own escape rooms. Then, a more detailed description of the procedure is given in every degree.

\subsection{Early Childhood Education Degree}

The activity was developed during the second semester of the subject. Until then, a total of five complete themes where given in class lessons, which were focused on the development of the contents referring to innovative methodologies in the classroom. In order for the students to be able to find a connection between the theory learned and a real and lived experience, the escape room began to be designed. Furthermore, it also served to articulate the narration, including challenges related with the contents given. The creation of the story, characters and challenges took a month, and the use of ICT was essential for that purpose. Below appear the tools used:

- Design and creation of video, audio and images: iMovie, Audacity, Renderforest and VLC.

- Design and creation of emblems, wild cards and challenges: Canva.

- Design of the tests of every challenge: eduescaperoom.com, on line crossword puzzles and word search games, metaverse and MergeCube.

\subsection{Social Education Degree}

After the positive results obtained with students of the Early Childhood Education degree, students of the Social Education degree were suggested to design escape rooms related with the contents given in the subjects of Permanent Education and Organization and Management of Educational Institutions for Social Intervention, from the 1st and 2nd course respectively. In this case, due to the own idiosyncrasy of the degree and the basis of the students, as many of them came from Advanced Vocational Training Modules, it was 
decided that they should create their own escape room working in collaborative groups. In particular, in the first course two escape rooms were performed, and in the second course, a total of nine. In Table 2 appear the selected themes for each team.

Table 2. Narratives and themes of escape rooms in Social Education

\begin{tabular}{|c|c|c|c|}
\hline \multirow{3}{*}{$\begin{array}{c}\text { Permanent } \\
\text { Education }\left(1^{\text {st }}\right)\end{array}$} & Theme-contents & Narrative & Main aspects \\
\hline & \multirow{2}{*}{$\begin{array}{l}\text { Education in } \\
\text { Adults and Older } \\
\text { People }\end{array}$} & $\begin{array}{l}\text { The Aging } \\
\text { Villain }\end{array}$ & $\begin{array}{l}\text { Based on a story of superheros and villains, } \\
\text { they work on empathy towards older people. }\end{array}$ \\
\hline & & $\begin{array}{c}\text { Alice in } \\
\text { Wonderland }\end{array}$ & $\begin{array}{l}\text { Through the story of Alice in Wonderland, } \\
\text { the intention is to work on the } \\
\text { education-employment advice for women of } \\
45+\text { who want to access the employment } \\
\text { market. }\end{array}$ \\
\hline \multirow{9}{*}{$\begin{array}{l}\text { Organization and } \\
\text { Management of } \\
\text { Educational } \\
\text { Institutions for } \\
\text { Social Intervention } \\
\left(2^{\text {nd }}\right)\end{array}$} & \multirow{9}{*}{$\begin{array}{l}\text { Conflict } \\
\text { settlement and } \\
\text { mediation in } \\
\text { school } \\
\text { environments. }\end{array}$} & $\begin{array}{l}\text { Money } \\
\text { Heist }\end{array}$ & $\begin{array}{l}\text { Based on the story of Money Heist, it } \\
\text { addresses the topic of violence and conflict } \\
\text { management in secondary education. }\end{array}$ \\
\hline & & SAW & $\begin{array}{l}\text { Related with the gore story of the film, } \\
\text { students articulate a narrative in order to } \\
\text { work on the cooperation among individuals } \\
\text { and the emotional management in secondary } \\
\text { education. }\end{array}$ \\
\hline & & CSI & $\begin{array}{l}\text { A kidnapping serves as a base to work on } \\
\text { moral values and teamwork in secondary } \\
\text { education. }\end{array}$ \\
\hline & & Egypt & $\begin{array}{l}\text { A treasure hunt set in ancient Egypt to work } \\
\text { on environmental education with primary } \\
\text { education students. }\end{array}$ \\
\hline & & $\begin{array}{l}\text { Harry } \\
\text { Potter }\end{array}$ & $\begin{array}{l}\text { The world of Harry Potter serves to develop } \\
\text { the acceptance of individual differences and } \\
\text { the respect for others, addressed to students } \\
\text { of primary and secondary education. }\end{array}$ \\
\hline & & Peter Pan & $\begin{array}{l}\text { Addressed to the students of Infant } \\
\text { Education, this theme intends to encourage } \\
\text { imagination, creativity and emotional } \\
\text { expression. }\end{array}$ \\
\hline & & $\begin{array}{l}\text { Pirates of } \\
\text { the } \\
\text { Caribbean }\end{array}$ & $\begin{array}{l}\text { A world of pirates serves to work on } \\
\text { immigration and interculturality with } \\
\text { baccalaureate students. }\end{array}$ \\
\hline & & The Purge & $\begin{array}{l}\text { Based on the narrative of the movie, } \\
\text { students tried to work the different aspects } \\
\text { of social exclusion and inequality of } \\
\text { opportunities in secondary education and } \\
\text { baccalaureate. }\end{array}$ \\
\hline & & $\begin{array}{l}\text { The Theft of } \\
\text { the Mona } \\
\text { Lisa }\end{array}$ & $\begin{array}{l}\text { In the prelude to a possible III World War } \\
\text { for the theft of the Mona Lisa, the intention } \\
\text { is to work on the respect for the culture and } \\
\text { value the informal and non-formal } \\
\text { education. Addressed to students from the } \\
\text { last courses of secondary education and } \\
\text { baccalaureate. }\end{array}$ \\
\hline
\end{tabular}




\subsection{Some Results}

The gamified activity (escape rooms) was only the final product of the innovation proposal carried out. Project-Based Learning (PBL) was the general methodology for the design and implementation of escape rooms in the Degree in Social Education, students had to carry out a project on school mediation for compulsory education, where they proposed gamification as final activity. On the other hand, in the Degree in Early Childhood Education, the methodology used was Flipped Classroom to present the lessons's content, the design and application of the escape room was destined to know the degree of knowledge acquisition, and its application to real contexts, about the work done in the classroom. Beyond the subject content itself and the methodology followed, the use of technology was established as a fundamental element, both for the design and for the implementation of innovation. The students affirmed the need to integrate ICT in their future professional practice.

Likewise, after carrying out the evaluation of the subjects of the Degrees in which the proposal was developed, an increase in the academic performance of the students was observed, as well as an increase in the ability to solve problems. For this, the results obtained in objective tests (exams), rubrics, co-evaluation targets and a final group debate to know the students' perceptions were taken into account.

Therefore, this section are reflected the perceptions of the students in a general way, as the analysis of the results is yet in preparation. A priori, students highlight the increase of the motivation, the boost of creativity and imagination and the development of the digital competence when using different resources and tools during the implementation process of the activity. More than $95 \%$ of the students consider that escape rooms are gamified activities that benefit the teaching-learning process and allow them to apply their knowledge in hypothetical environments that could be found in their future work.

\section{CONCLUSIONS}

The first experiences of escape rooms carried out in Higher Education, were performed in degrees like Medicine (Kinio, Dufresne, Brandys, \& Jetty, 2017; See, Lam, \& Lau, 2016), Nursing (Adams, Burger, Crawford, \& Setter, 2018), Engineering and Information Technology (Borrego, Fernández, Blanes, \& Robles, 2017) and Chemistry (Dietrich, 2018).

In conclusion, escape rooms promote communication, collaborative and cooperative work, the development of lateral and critical thinking, as well as the need to pay attention to details. Moreover, any individual can access them, regardless of age. Regarding this, teams that maintain a high level of success are those composed by people of different age ranges, with a variety of life experiences, skills and abilities, whether physical or mental (Nicholson, 2018). Furthermore, the development of the digital competence is essential for the elaboration of resources, not only for this kind of activities, but also for life in general. Hence, it is considered that the proposal is beneficial and highly potential for the acquisition of the competences that are actually requested in order to function within society and its different spheres.

\section{REFERENCES}

Adams, V., Burger, S., Crawford, K., \& Setter, R. (2018). Can You Escape? Creating an Escape Room to Facilitate Active Learning. Journal for Nurses in Professional Development, 34(2), E1. https://doi.org/10.1097/NND.0000000000000433

Borrego, C., Fernández, C., Blanes, I., \& Robles, S. (2017). Room escape at class: Escape games activities to facilitate the motivation and learning in computer science. Journal of Technology and Science Education, 7(2), 162-171. https://doi.org/10.3926/jotse.247

Csikszentmihalyi, M. (2012). Fluir: Una psicología de la felicidad. Editorial Kairós.

Deterding, S., Dixon, D., Khaled, R., \& Nacke, L. (2011). From game design elements to gamefulness: Defining gamification. Proceedings of the 15th international academic MindTrek conference: Envisioning future media environments, 9-15. https://doi.org/10.1145/2181037.2181040 
Deterding, S., Sicart, M., Nacke, L., O’Hara, K., \& Dixon, D. (2011). Gamification. Using Game-design Elements in Non-gaming Contexts. CHI '11 Extended Abstracts on Human Factors in Computing Systems, 2425-2428. https://doi.org/10.1145/1979742.1979575

Dietrich, N. (2018). Escape Classroom: The Leblanc Process-An Educational "Escape Game". Journal of Chemical Education. https://doi.org/10.1021/acs.jchemed.7b00690

EducaLab. (2015). 8 cosas que debes saber sobre el juego y la pedagogía. Recuperado 25 de mayo de 2018, de ¿Jugamos? La Gamificación | Dale la vuelta a tu clase (Flipped Classroom) website: http://formacion.educalab.es/pluginfile.php/43566/mod_imscp/content/1/jugamos_la_gamificacin.html

Kinio, A., Dufresne, L., Brandys, T., \& Jetty, P. (2017). Break Out of the Classroom: The Use of Escape Rooms as an Alternative Learning Strategy for Surgical Education. Journal of Vascular Surgery, 66(3), e76. https://doi.org/10.1016/j.jvs.2017.07.034

Nicholson, S. (2015). Peeking behind the locked door: A survey of escape room facilities. Recuperado de http://scottnicholson.com/pubs/erfacwhite.pdf

Nicholson, S. (2018). Creating Engaging Escape Rooms for the Classroom. Childhood Education, 94(1), 44-49. https://doi.org/10.1080/00094056.2018.1420363

Ochoa, A. D. (2014, octubre 27). Incorporación del juego en la escuela. Recuperado 25 de mayo de 2018, de The Flipped Classroom website: https://www.theflippedclassroom.es/incorporacion-del-juego-en-la-escuela/

Rice, J. W. (2012). The Gamification of Learning and Instruction: Game-Based Methods and Strategies for Training and Education. International Journal of Gaming and Computer-Mediated Simulations (IJGCMS), 4(4), 81-83. https://doi.org/10.4018/jgcms.2012100106

See, C. Y. H., Lam, T. P., \& Lau, W. C. S. (2016). The design, implementation and evaluation of an Escape-Room as a form of game-based learning in medical education. Recuperado de http://hub.hku.hk/handle/10722/250222

Simkins, D. (2015). The Arts of LARP: Design, Literacy, Learning and Community in Live-Action Role Play. McFarland.

Wang, M., Callaghan, V., Bernhardt, J., White, K., \& Peña-Rios, A. (2018). Augmented reality in education and training: Pedagogical approaches and illustrative case studies. Journal of Ambient Intelligence and Humanized Computing, 9(5), 1391-1402. https://doi.org/10.1007/s12652-017-0547-8 